Article

\title{
Gold Partitioning in a Model Multiphase Mineral-Hydrothermal Fluid System: Distribution Coefficients, Speciation and Segregation
}

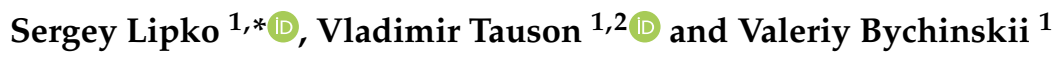 \\ 1 A.P. Vinogradov Institute of Geochemistry, Siberian Branch of Russian Academy of Sciences, \\ 664033 Irkutsk, Russia; vltauson@igc.irk.ru (V.T.); val@igc.irk.ru (V.B.) \\ 2 Irkutsk Scientific Center, Siberian Branch of Russian Academy of Sciences, 664033 Irkutsk, Russia \\ * Correspondence: slipko@yandex.ru; Tel.: +7-3952-429-967
}

Received: 20 August 2020; Accepted: 6 October 2020; Published: 7 October 2020

check for updates

\begin{abstract}
The characteristics of Au partitioning in a multiphase, multicomponent hydrothermal system at $450{ }^{\circ} \mathrm{C}$ and $1 \mathrm{kbar}$ pressure were obtained using experimental and computational physicochemical modelling and laser ablation inductively coupled plasma mass spectrometry (LA-ICP-MS) analysis. Sphalerite and magnetite contained $0.1-0.16 \pm 0.02 \mu \mathrm{g} / \mathrm{g}$ Au and coexisted with galena and bornite which contained up to $73 \pm 5$ and $42 \pm 10 \mu \mathrm{g} / \mathrm{g} \mathrm{Au}$, respectively. Bornite and chalcopyrite were the most effective Au scavengers with cocrystallization coefficients $\mathrm{Au} / \mathrm{Fe}$ and $\mathrm{Au} / \mathrm{Cu}$ in mineral-fluid system $n-n \times 10^{-2}$. Sphalerite and magnetite were the weakest Au absorbers, although Fe impurity in sphalerite facilitated Au uptake. Using the phase composition correlation principle, Au solubility in minerals was estimated $(\mu \mathrm{g} / \mathrm{g} \mathrm{Au})$ : low-Fe sphalerite $=0.7$, high-Fe sphalerite $=5$, magnetite $=1$, pyrite $=3$, pyrite-Mn $=7$, pyrite- $\mathrm{Cu}=10$, pyrrhotite $=21$, chalcopyrite $=110$, bornite $=140$ and galena $=240$. The sequence reflected increasing metallicity of chemical bonds. Gold segregation occurred at crystal defects, and on surfaces, and influenced Au distribution due to its segregation at crystal interblock boundaries enriched in Cu-containing submicron phases. The LA-ICP-MS analysis of bulk and surficial gold admixtures revealed elevated Au content in surficial crystal layers, especially for bornite and galena, indicating the presence of a superficial nonautonomous phase (NAP) and dualism in the distribution of gold. Thermodynamic calculations showed that changes in experimental conditions, primarily in sulfur regime, increased the content of the main gold species $\left(\mathrm{AuCl}_{2}^{-}\right.$and $\mathrm{AuHS}^{0}$ ) and decreased the content of $\mathrm{FeCl}_{2}^{0}$, the prevailing form of iron in the fluid phase. The elevation of $\mathrm{S}_{2}$ and $\mathrm{H}_{2} \mathrm{~S}$ fugacity affected $\mathrm{Au}$ partitioning and cocrystallization coefficients. Using $\mathrm{Au}$ content in pyrite, chalcopyrite, magnetite and bornite from volcanic-sedimentary, skarn-hosted and magmatic-hydrothermal sulfide deposits, the ranges of metal ratios in fluids were estimated: $\mathrm{Au} / \mathrm{Fe}=n \times 10^{-4}-n \times 10^{-7}$ and $\mathrm{Au} / \mathrm{Cu}=n \times 10^{-4}-n \times 10^{-6}$. Pyrite and magnetite were crystallized from solutions enriched in Au compared to chalcopyrite and bornite. The presence of NAP, and associated dualism in distribution coefficients, strongly influenced Au partitioning, but this effect does not fully explain the high gold fractionation into mineral precipitates in low-temperature geothermal systems.
\end{abstract}

Keywords: gold; hydrothermal system; distribution; cocrystallization coefficient; thermodynamic modeling; fluid composition; superficial segregation; gold solid state solubility; sulfide mineral; magnetite; LA-ICP-MS

\section{Introduction}

Gold distribution among coexisting ore minerals, as well as between minerals (precipitates or solid phase) and hydrothermal fluids (aqueous phase), presents a fascinating geochemical problem. 
For example, Yang et al. [1] suggested the following trend (series) in ability of ore minerals to host $\mathrm{Au}$ in decreasing order (figures in parentheses are metal-to-sulfur ratios in the formulas of sulfides): bornite (1.5) > chalcopyrite (1.0) > pyrrhotite (0.87-0.99) > pyrite (0.5). To the contrary, many authors demonstrated that pyrite (especially its arsenian variety) is the best gold concentrator in ore deposits, comparable only to arsenopyrite [2-4]. Several reasons exist for which this problem remains unsolved until now. First, the data for natural objects are difficult to interpret because of the complicated history and poor understanding of processes, transformations and solid-state and heterogeneous reactions in ancient mineral systems. Moreover, the results of bulk analytical methods are usually inconsistent. For example, spectrographic analyses showed similar average Au contents [5] (p. 194) in the minerals of hydrothermal assemblages of pyrite, arsenopyrite, sphalerite and galena at the El Sid gold mine (Eastern Desert, Egypt). However, gold content varied greatly in different samples from the mine (ppm: 19-210 in pyrite, 5-535 in arsenopyrite, 10-181 in sphalerite, and 15-115 in galena).

Modern hydrothermal vent systems provide the opportunity to study Au distribution in ore sulfides [6], but difficulties arise in collecting fresh samples due to the fine intergrowths of Au at low concentrations in small grains of minerals. The experimental approach might provide data on Au partitioning that are more reliable than the data for natural systems, although for trace elements such as $\mathrm{Au}$, which is indifferent to the majority of ore and rock-forming mineral matrixes, several important questions arise relevant to Au speciation, segregation and crystal growth in multiphase hydrothermal systems [7-9]. The purpose of this work was to evaluate geochemical and physicochemical factors that regulate speciation, incorporation and partitioning of gold in complex mineral systems under hydrothermal conditions. The term mineral in this work refers to a synthetic crystalline phase analogous, but not fully identical, to a real mineral object. This phase, formed under similar (hydrothermal) conditions, presents a fine model for studying behavior of real minerals and fluid components. The mineral names are kept for the ease of presentation.

Another geochemical problem is the estimation of Au content in ore-forming fluids. To address this objective, experimental data on Au distribution and cocrystallization coefficients, together with data on gold content as a structural admixture in gold-bearing minerals, were used. Gold-containing minerals were expected to vary in composition with respect to gold. At the present time, this problem is solved by elemental analysis using laser ablation inductively coupled plasma mass spectrometry (LA-ICP-MS) on individual fluid inclusions. However, this method has disadvantages. As a rule, it is applied to transparent vein minerals (quartz, calcite) which may not have formed simultaneously with the Au-bearing mineral. Zajacz et al. [10] showed that the gas-liquid inclusions could not adequately preserve several easily-diffused elements that can migrate in structural channels along the c-direction of the quartz lattice. High diffusion rates characterize monovalent cations $\left(\mathrm{H}^{+}, \mathrm{Li}^{+}, \mathrm{Na}^{+}, \mathrm{Cu}^{+}, \mathrm{Ag}^{+}\right)$ comparable in size with the diameter of the structural channel, whereas multicharged and large cations demonstrate stability. Moreover, $\mathrm{Au}+$ content might have changed over geologic time because microheterogeneous systems are modified over time due to excess interphase free energy. However, the main advantages of using Au-containing minerals of variable composition over fluid inclusions to estimate Au content are: (1) greater scale of sampling because modern methods such as LA-ICP-MS and SIMS (secondary ion mass spectrometry) allow Au determination to a level of 0.1 ppm in many Au-containing crystals, whereas useful inclusions are rare; (2) opportunity to study dispersed mineral systems (sedimentary, diagenetic, sea-floor sulfide chimneys and mounds, and many others), which are currently beyond the ability of fluid inclusion techniques. The fine-grained samples present a problem for Au analytics as well, but high spatial resolution of current methods suffices in some cases.

\section{Materials and Methods}

\subsection{Experimental Procedure}

Crystals of coexisting minerals were obtained using standard techniques of hydrothermal thermogradient synthesis in stainless steel $\left(200 \mathrm{~cm}^{3}\right)$ autoclaves equipped with titanium alloy (VT-8) 
passivated inserts, with a volume of $\sim 50 \mathrm{~cm}^{3}$ (Table 1). The internal sampling method was used to obtain data on the composition of the high temperature fluid phase [7]. The temperature in the zone of crystal growth was $450{ }^{\circ} \mathrm{C}$ and the pressure was $100 \mathrm{MPa}(1 \mathrm{kbar})$. The $\mathrm{P}, \mathrm{T}$ - parameters were chosen bearing in mind the possibility of data comparison with the results of preceding experimental works (Section 4.1.). Another reason was the optimal combination of temperature and pressure high enough for near-equilibrium crystal growth of multiphase assemblages and for trapping fluid quantity required for analysis. The full duration was 24 days with the first 4 days in an isothermal regime to homogenize the batch material and ensure near-equilibrium conditions for the subsequent 20 days of thermogradient recrystallisation maintained with a $15{ }^{\circ} \mathrm{C}$ temperature drop (on the outer wall of the autoclave). The actual temperature gradient in the reaction vessel for such a configuration was no more than $0.1^{\circ} \mathrm{C} / \mathrm{cm}$. The experiments were terminated by autoclave quenching in cold running water at a rate of $5{ }^{\circ} \mathrm{C} / \mathrm{s}$. After the insert disclosure, the solution was immediately extracted from the sampler, which was rinsed with aqua regia to dissolve precipitate. The cleaning solution was subsequently combined with the directly extracted one. Thereafter, a special chemical medium was created to determine the elements by atomic absorption spectrometry (AAS). The large-volume pressure vessel quenching process was not stationary and sometimes the fluid trapped expelled from the sampler. This occurred during an experiment (Experiment 3, Table 1), where $\mathrm{K}_{2} \mathrm{Cr}_{2} \mathrm{O}_{7}$ was added to improve magnetite growth, suppressed in the presence of growing sulfide phases. The batch was made up from domestically produced reagents of high chemical purity (pure reagent-grade). The amounts of components in the batch were fitted empirically according to experimental work with similar systems. An optimal solid-to-liquid ratio for multiphase growth of crystals in sulfide systems was applied. The batch weighed $6 \mathrm{~g}$ and consisted of metal sulfides and metallic Fe; in two cases, elemental $\mathrm{S}$ was added aiming the pyrite formation in the phase assemblage. Gold of 999.9 fineness was used as a foil (20 mg). The weighed gold was enough for retaining $\mathrm{Au}^{\circ}$ phase in the system, which is important for physicochemical modelling. Solutions were based on ammonium chloride (Table 1). Five and ten percent aquatic solutions were reported as the most effective mineralizers for growing oxide and sulfide crystals [7].

Table 1. Conditions and results of hydrothermal experiments on synthesis of multiphase assemblages and study of Au partitioning at $450{ }^{\circ} \mathrm{C}$ and 1 kbar pressure.

\begin{tabular}{|c|c|c|c|c|c|c|c|c|c|c|c|c|c|c|c|}
\hline \multirow[b]{2}{*}{$\begin{array}{l}\text { Experiment } \\
\text { No. }\end{array}$} & \multicolumn{3}{|c|}{ Solution } & \multicolumn{5}{|c|}{ Batch Composition (g) $^{a}$} & \multirow[b]{2}{*}{ Phases Obtained ${ }^{b}$} & \multicolumn{6}{|c|}{ Solution in Sampler } \\
\hline & Composition & $\begin{array}{c}\text { Insert } \\
\text { Volume } \\
\left(\mathrm{cm}^{3}\right)\end{array}$ & $\begin{array}{l}\text { Fluid } \\
\text { Density } \\
\left(\mathrm{g} / \mathrm{cm}^{3}\right)\end{array}$ & ZnS & $\mathrm{PbS}$ & $\mathrm{Cu}_{2} \mathrm{~S}$ & $\mathrm{Fe}$ & $S$ & & $\mathrm{pH}$ & $\underset{(\mu \mathrm{g} / \mathrm{g})}{\mathrm{Au}}$ & $\begin{array}{l}\mathrm{Zn} \\
(\mathbf{w t} \%)\end{array}$ & $\begin{array}{c}\mathrm{Fe} \\
(\mathrm{wt} \%)\end{array}$ & $\begin{array}{l}\mathrm{Cu} \\
(w t \%)\end{array}$ & $\begin{array}{c}\mathrm{Pb} \\
(\mathbf{w t} \%)^{c}\end{array}$ \\
\hline 2 & $10 \% \mathrm{NH}_{4} \mathrm{Cl}$ & 54.5 & 0.69 & 1.8 & 1.8 & 1.2 & 1.2 & - & Sph, Mt, Bn, Gn, Cpy & 7.5 & 0.61 & 1.24 & 1.0 & 0.027 & $>0.06$ \\
\hline 3 & $\begin{array}{c}10 \% \mathrm{NH}_{4} \mathrm{Cl} \\
+2 \% \\
\mathrm{~K}_{2} \mathrm{Cr}_{2} \mathrm{O}_{7}\end{array}$ & 55.4 & 0.7 & 1.8 & 1.8 & 1.2 & 1.2 & - & Sph, Mt, Gn & 7.6 & & etermin & $\begin{array}{l}\text { hed (not } \\
\text { trapped) }\end{array}$ & $\begin{array}{l}\text { t enougl } \\
\text { d) }\end{array}$ & fluid \\
\hline 4 & $5 \% \mathrm{NH}_{4} \mathrm{Cl}$ & 61.9 & 0.65 & 1.8 & 1.8 & 0.6 & 0.9 & 0.9 & Sph, Gn, Py, Cpy & 6.5 & 1.94 & 2.31 & 0.62 & 0.084 & $>0.61$ \\
\hline 5 & $10 \% \mathrm{NH}_{4} \mathrm{Cl}$ & 58.3 & 0.69 & 1.8 & 1.8 & 0.6 & 0.9 & 0.9 & Sph, Gn, Py, Bn & 6.5 & 2.56 & 3.21 & 0.22 & 0.055 & $>0.26$ \\
\hline
\end{tabular}

${ }^{a}$ Batch weight was $6 \mathrm{~g}$. Au was added as a foil $(20 \mathrm{mg}) .{ }^{b} \mathrm{Sph}$-sphalerite, Mt—magnetite, Bn-bornite, Gn-galena, Cpy-chalcopyrite, Py-pyrite. ${ }^{c}$ Minimal estimate (without accounting for $\mathrm{PbCl}_{2}$ precipitated from solution in the sampler). ${ }^{d}$ Few individual crystals; mainly patches on crystals of other phases.

\subsection{Analytical Methods}

The diagnostics of the phases obtained, measurements of unit cell edges and crystallite sizes were performed with a D8 ADVANCE diffractometer (Bruker, Karlsruhe, Germany) using EVA software (DIFFRAC Plus Evaluation package EVA; user's Manual, Bruker AXS, 2007, Karlsruhe, Germany). Uncertainties in unit cell edges were at the level of $\pm 1-2 \times 10^{-5} \mathrm{~nm}$, crystallite sizes $\pm 1-2 \mathrm{~nm}$.

AAS measurements were performed on a Perkin-Elmer Model 503 and Analyst 800 (The Perkin Elmer Corp., Norwalk, CT, USA) devices. Gold in solution from the sampler was determined by AAS with element electrothermal atomization in a graphite furnace (AAS-GF). Measurements were made to a precision of $\pm 12 \%$, with a minimum detection limit (MDL) of $0.3 \mu \mathrm{g} / \mathrm{L}(0.3 \mathrm{ppb})$. Other elements ( $\mathrm{Zn}$, 
$\mathrm{Fe}, \mathrm{Cu}, \mathrm{Pb}$ ) were determined with a precision of $\pm 5 \%$. The element concentrations were calculated by an external calibration method using in-house standard solutions prepared from analytically pure substances. The crystals obtained were studied by LA-ICP-MS using two approaches. The first approach included analysis on polished crystal sections pressed into epoxy cartridges (i.e., the data obtained refer to the volume content of $\mathrm{Au}$ ). In the second approach, native crystal faces were analyzed, which was possible when the crystals were large enough (up to $2 \mathrm{~mm}$ ). The depth of the hole following laser evaporation of the material by microscopic methods (light microscopy, scanning electron microscopy) was $\leq 20 \mu \mathrm{m}$ [7]. Gold determination was performed using two standard samples: the glass sample NIST $612(4.9 \pm 0.3 \mathrm{ppm} \mathrm{Au})$ from the National Institute of Standards and Technology (NIST), and the in-house sulfide sample MA4-1, highly homogeneous single crystals of greenockite $(\alpha-\mathrm{CdS})$ synthesized hydrothermally at $500{ }^{\circ} \mathrm{C}$ and $1 \mathrm{kbar}$ and containing $45 \pm 3 \mathrm{ppm} \mathrm{Au}$. The Au content divergence was within $\pm 30 \%$ relative, although the standard deviation in the first case was 1.5 times higher, probably due to inhomogeneity of Au distribution in the glass standard sample. The LA-ICP-MS measurements were performed on an Agilent 7500ce unit manufactured by Agilent Technologies with a quadrupole mass analyzer (Agilent Tech., Santa Clara, CA, USA). The laser ablation platform of the New Wave Research UP-213 was used. Parameters of the LA-ICP-MS experiment were (figures in parentheses refer to polished crystals): plasma power 1580 (1400) W, carrier gas flow rate $1.24(1.22) \mathrm{L} / \mathrm{min}$, plasma forming gas flow rate $15 \mathrm{~L} / \mathrm{min}$, cooling gas $1 \mathrm{~L} / \mathrm{min}$, laser power $100 \%(90 \%)$, wavelength $213 \mathrm{~nm}$, frequency $20 \mathrm{~Hz}$ and laser spot diameter $100 \mu \mathrm{m}$ (55), number of channels per mass 3, accumulation time per channel $0.15 \mathrm{~s}$, and acquisition time $30 \mathrm{~s} \mathrm{(10).} \mathrm{For} \mathrm{polished} \mathrm{minerals,}$ measurements were made at 20 points in each sample, at three to four points in several (three to five) crystals of each sample. The calculated MDL values amounted to 0.23 and $0.12 \mathrm{ppm}(\mu \mathrm{g} / \mathrm{g})$ for native surface and polished crystals, respectively. The contents of all mineral-forming elements belonging to the system were controlled at each point, which allowed elimination of cases when the point analyzed was attributed to the inclusion of another (coexisting) phase.

\subsection{Physicochemical Modelling}

A comprehensive physicochemical model was developed to study ore-forming processes on the basis of the program complex (PC) Selector in the Vinogradov Institute of Geochemistry SB RAS [11,12]. Several algorithms are used for studying multicomponent natural and technological processes under a wide range of thermodynamic parameters. PC represents an advanced program instrument incorporating the algorithm of free energy minimization by the method of convex programing for thermodynamic modelling of natural processes. In modelling of real experimental systems, the initial data include the chemical composition of the charge (or interacting substances) and the thermodynamic properties of dependent components such as melts, solutions, solid phases and gases. In the present work, the isobar-isothermal equilibrium in the system S-Zn-Pb-Cu-Fe-Cl-N-Au-H-O was calculated by minimization of Gibbs free energy value at $450{ }^{\circ} \mathrm{C}$ and 997 bars pressure. The chemical composition varied according to experimental conditions (Table 1).

\section{Results}

\subsection{Experimental Results}

Crystals in multimineral assemblages synthesized in the experiments ranged in size from a fraction of a millimeter up to two to three $\mathrm{mm}$. The largest and most perfect ones were selected for analysis (Figure 1). Smooth clean crystal faces were rarely observed, so reproducible data on Au content in the surface layers of coexisting mineral crystals in the same experiment were obtained by LA-ICP-MS in only one case (Experiment 5, Table 1). Table 2 presents the results of Au determination with LA-ICP-MS and AAS data on Fe content in sphalerite. 


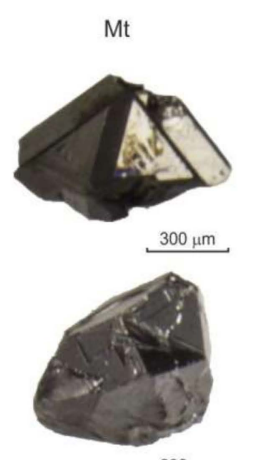

$200 \mu \mathrm{m}$

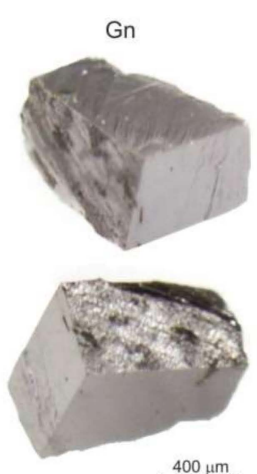

$400 \mu \mathrm{m}$

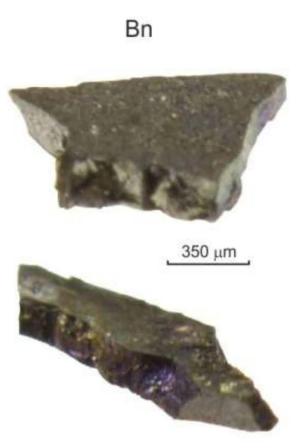

$400 \mu \mathrm{m}$

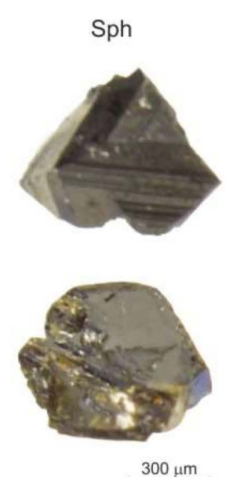

$300 \mu \mathrm{m}$

Figure 1. Crystals of magnetite (Mt), galena $(\mathrm{Gn})$, bornite $(\mathrm{Bn})$ and sphalerite (Sph) synthesised in multiphase assemblage under hydrothermal conditions $\left(450{ }^{\circ} \mathrm{C}, 100 \mathrm{MPa}, \mathrm{NH}_{4} \mathrm{Cl}\right.$ solution).

Table 2. Au content in minerals determined by laser ablation inductively coupled plasma mass spectrometry (LA-ICP-MS); Fe content in sphalerite by atomic absorption spectrometry; coexisting minerals were synthesized in hydrothermal experiments at $450{ }^{\circ} \mathrm{C}$ and $1 \mathrm{kbar}$.

\begin{tabular}{cccccccc}
\hline \multirow{2}{*}{$\begin{array}{c}\text { Experiment } \\
\text { No. }\end{array}$} & $\begin{array}{c}\text { Fe in Sph } \\
(\mathbf{w t} \% \text { AAS) }\end{array}$ & Sph & Mt & Gn & Cpy & Bn & Py \\
\cline { 3 - 7 } & 2.8 & $0.16 \pm 0.02$ & $0.15 \pm 0.02$ & $73 \pm 5$ & n.d. $b$ & $42 \pm 10$ & - \\
1 & 3.4 & $0.11 \pm 0.02$ & $\leq 0.1$ & $28 \pm 1$ & $13 \pm 5$ & $17 \pm 3$ & - \\
2 & 4.1 & $0.14 \pm 0.03$ & $0.12 \pm 0.02$ & $47 \pm 2$ & - & - & - \\
3 & 1.8 & $\leq 0.1$ & - & $600 \pm 30^{c}$ & $15 \pm 2$ & - & $2 \pm 2$ \\
4 & 1.3 & $\leq 0.1$ & - & $9.9 \pm 0.3$ & - & $10.2^{b} \pm 0.2$ & $9.7 \pm 0.2^{d}$ \\
5 & & & &
\end{tabular}

$\bar{a} 1 \sigma$ at a confidence level of 0.95 . See Table 1 for abbreviation of minerals. ${ }^{b}$ Not determined. ${ }^{c}$ Heterogeneous crystals enriched in Cu-phases, see text for explanation. ${ }^{d}$ Evenly distributed (structural?) copper in pyrite $(2000 \pm 700 \mu \mathrm{g} / \mathrm{g} \mathrm{Cu})$.

Gold content in sphalerite was close to the MDL. However, its positive correlation with $\mathrm{Au}$ in galena and bornite may be indicative of isomorphous $\mathrm{Au}$ incorporation subjecting the principle of phase composition correlation, the regular change in compositions of coexisting phases under variation of intensive parameters of the system [13]. The same situation occurred in the case of magnetite, for which correlation of Au content with galena also occurred (Experiments 1-3, Table 2). The situation was more complicated when pyrite appeared in the mineral assemblage (Experiments 4 and 5, Table 2). First, we noted that galena contained much higher Au than is possible according to its incorporation limit $(240 \mu \mathrm{g} / \mathrm{g})$ [13]. Galena crystals from Experiment 4 exhibited an interesting phenomenon previously described in similar hydrothermal multisystems with copper. Tauson et al. [14] (p. 951) noted that ' $\ldots$ studies of galena in such systems ... may encounter difficulties associated with its very close relationship with copper sulfides'. The crystals from this experiment were characterized by relatively small block (crystallite) dimensions $(52 \mathrm{~nm}$ ) and actually represented heteroepitaxial (syntaxy) structures in which nanofilms of chalcopyrite, or other copper sulfides, occupied internal surfaces (interblock cleavage faces) and external surfaces (crystal faces). These films can well be seen with a light microscope due to specific tarnishing of cleavage faces. Such structures are thought to be highly active in trapping atoms of impurity similar to the admixture uptake by dislocation pile-ups [15]. Most likely this is a consequence of a specific mechanism of crystal growth in such complicated systems (see Section 4.4. and [7-9]), which disturbs the principle of phase composition correlation for ideal crystals.

Experiment 5 demonstrated another feature of the pyrite-containing association: a tendency to equalize Au content in all coexisting minerals except for sphalerite (Table 2). Moreover, gold distribution throughout individual crystals, and among crystals of each mineral, was highly homogeneous (relative standard deviation $2 \%$ ). One possible reason is that a relatively homogeneous $\mathrm{Cu}$ impurity amounted to $0.20 \pm 0.07 \mathrm{wt} \%$ in pyrite crystals in this experiment. If $\mathrm{Cu}$ represents a structural admixture, $\mathrm{Au}$ distribution might depend on $\mathrm{Cu}$ content and not obey Nernst's law demonstrating the 
same distribution coefficient as for pure mixed crystals $(\mathrm{Fe}, \mathrm{Au}) \mathrm{S}_{2}$. Incorporation of gold into the pyrite structure may occur according to the mechanism $\mathrm{Au}^{3+}+\mathrm{Cu}^{+}=2 \mathrm{Fe}^{2+}$ proposed by Chouinard et al. [16]. However, a definite decrease in unit cell edge $(a=0.54137 \mathrm{~nm}$, compared with $0.5420 \mathrm{~nm}$ for ordinary hydrothermal pyrite) may indicate gold incorporation as Au+ accompanied by neutral metal vacancy: $\mathrm{Au}^{+}+\mathrm{Cu}^{+}=\mathrm{Fe}^{2+}+\mathrm{V}_{\mathrm{Fe}}$. This mechanism probably operated under slightly higher sulfur activity than in Exp. 4 (see Section 3.2.).

Table 3 shows Au distribution coefficients between solid and fluid phases for all minerals obtained in the experiments. It can be seen that Au behaves as compatible to highly compatible element in galena, bornite and chalcopyrite. Lower compatibility was a feature of pyrite, and incompatibility was characteristic of sphalerite and magnetite. The $D^{\mathrm{min} / \mathrm{aq}}$ values roughly characterized the relative ability of a mineral to concentrate gold because all coexisting minerals were grown together under similar conditions.

Table 3. Gold partition coefficients in the mineral- aqueous fluid system: LA-ICP-MS data for bulk of crystals grown simultaneously at $450{ }^{\circ} \mathrm{C}$ and 1 kbar.

\begin{tabular}{ccccccc}
\hline \multirow{2}{*}{$\begin{array}{c}\text { Experiment } \\
\text { No. }\end{array}$} & Sphalerite & Magnetite & Galena & Chalcopyrite & Bornite & Pyrite \\
\cline { 2 - 7 } & $0.16 \pm 0.04$ & $0.15 \pm 0.03$ & $73 \pm 12$ & n.d. & $42 \pm 14$ & - \\
1 & $0.18 \pm 0.05$ & $\leq 0.16$ & $45 \pm 6$ & $21 \pm 10$ & $27 \pm 7$ & - \\
2 & $\leq 0.05$ & - & $310 \pm 50^{a}$ & $8 \pm 2$ & - & $1 \pm 1$ \\
4 & $\leq 0.04$ & - & $3.9 \pm 0.5$ & - & $4.0 \pm 0.5$ & $3.8 \pm 0.4^{b}$ \\
5 & & &
\end{tabular}

Note: n.d.-not determined. " Heterogeneous crystals enriched in Cu-phases, see text for explanation.

${ }^{b} \mathrm{Cu}$-containing pyrite with $0.20 \pm 0.07 \mathrm{wt} \% \mathrm{Cu}$.

The gold-to-metal cocrystallization coefficients were calculated from the data in Tables 1 and 2 and presented in Table 4. These are bulk coefficients with respect to solution because they disregard Au and $\mathrm{Me}(\mathrm{Zn}, \mathrm{Fe}, \mathrm{Cu})$ species and their activity in the solution. For binary metal minerals (chalcopyrite, bornite, Fe-sphalerite), three versions were considered: (1 and 2) for each of two metals and (3) for the sum of metals that can be substituted by $\mathrm{Au}\left(D_{\mathrm{Au} /(\mathrm{Zn}+\mathrm{Fe})}\right.$ in sphalerite, $D_{\mathrm{Au} /(\mathrm{Cu}+\mathrm{Fe})}$ in chalcopyrite and bornite).

Table 4. Gold/metal cocrystallization coefficients in the mineral-aqueous fluid system at $450{ }^{\circ} \mathrm{C}$ and $1 \mathrm{kbar}$.

\begin{tabular}{|c|c|c|c|c|c|c|c|c|c|c|c|}
\hline \multirow{3}{*}{$\begin{array}{c}\text { Experiment } \\
\text { No. }\end{array}$} & \multicolumn{11}{|c|}{$D_{\mathrm{Au} / \mathrm{Me}}^{\mathrm{min} / \mathrm{aq}}=\left(C_{\mathrm{Au}} / C_{\mathrm{Me}}\right)^{\mathrm{min}} /\left(C_{\mathrm{Au}} / C_{\mathrm{Me}}\right)^{\mathrm{aq}}$} \\
\hline & \multicolumn{3}{|c|}{ Sphalerite } & \multicolumn{2}{|c|}{ Magnetite } & \multicolumn{2}{|c|}{ Chalcopyrite } & \multicolumn{3}{|c|}{ Bornite } & \multirow{2}{*}{$\begin{array}{c}\text { Pyrite } \\
\text { Fe }\end{array}$} \\
\hline & $\begin{array}{c}\mathrm{Zn}+ \\
\mathrm{Fe}\end{array}$ & Zn & $\mathrm{Fe}$ & $\mathrm{Fe}$ & $\begin{array}{c}\mathrm{Cu}+ \\
\mathrm{Fe}\end{array}$ & $\mathrm{Cu}$ & $\mathbf{F e}$ & $\begin{array}{c}\mathrm{Cu}+ \\
\mathrm{Fe}\end{array}$ & $\mathrm{Cu}$ & $\mathrm{Fe}$ & \\
\hline 1 & $\begin{array}{c}5.01 \times \\
10^{-3}\end{array}$ & $\begin{array}{c}3.68 \times \\
10^{-3}\end{array}$ & $\begin{array}{c}3.54 \times \\
10^{-2}\end{array}$ & $\begin{array}{c}1.29 \times \\
10^{-3}\end{array}$ & - & - & - & 0.37 & $\begin{array}{c}2.19 \times \\
10^{-2}\end{array}$ & 2.34 & - \\
\hline 2 & $\begin{array}{c}6.02 \times \\
10^{-3}\end{array}$ & $\begin{array}{c}3.51 \times \\
10^{-3}\end{array}$ & $\begin{array}{c}5.30 \times \\
10^{-2}\end{array}$ & $\begin{array}{c}\leq 2.27 \\
\times \\
10^{-3}\end{array}$ & 0.34 & $\begin{array}{c}1.66 \times \\
10^{-2}\end{array}$ & 0.70 & 0.38 & $\begin{array}{c}1.19 \times \\
10^{-2}\end{array}$ & 2.50 & - \\
\hline 4 & $\begin{array}{c}\leq 2.25 \\
\times \\
10^{-3}\end{array}$ & $\begin{array}{c}\leq 1.82 \\
\times \\
10^{-3}\end{array}$ & $\begin{array}{c}\leq 1.78 \\
\times \\
10^{-2}\end{array}$ & - & $\begin{array}{c}8.37 \times \\
10^{-2}\end{array}$ & $\begin{array}{c}1.88 \times \\
10^{-2}\end{array}$ & 0.16 & - & - & - & $\begin{array}{c}1.37 \times \\
10^{-2}\end{array}$ \\
\hline 5 & $\begin{array}{c}\leq 2.0 \\
\times \\
10^{-3}\end{array}$ & $\begin{array}{c}\leq 1.91 \\
\times \\
10^{-3}\end{array}$ & $\begin{array}{c}\leq 6.61 \\
\times \\
10^{-3}\end{array}$ & - & - & - & - & $\begin{array}{c}1.47 \times \\
10^{-2}\end{array}$ & $\begin{array}{c}3.46 \times \\
10^{-3}\end{array}$ & $\begin{array}{c}7.88 \times \\
10^{-2}\end{array}$ & $\begin{array}{c}1.79 \times \\
10^{-2}\end{array}$ \\
\hline
\end{tabular}

Table 4 shows that the most effective $\mathrm{Au}$ concentrators were bornite and chalcopyrite $\left(D_{\mathrm{Au} / \mathrm{Me}}^{\mathrm{min} / \mathrm{q}}=n-n \times 10^{-2}\right)$. The data on bornite in Exp. 5 were sufficiently lower than in Experiment 1 and 2, which are in accordance with each other. Possible reasons will be considered below (see Section 3.2). Sphalerite and magnetite were the weakest $\mathrm{Au}$ absorbers, although Fe in sphalerite facilitated Au uptake elevating $D_{\mathrm{Au} /(\mathrm{Zn}+\mathrm{Fe})}$ by a factor of 3 (Figure 2). 


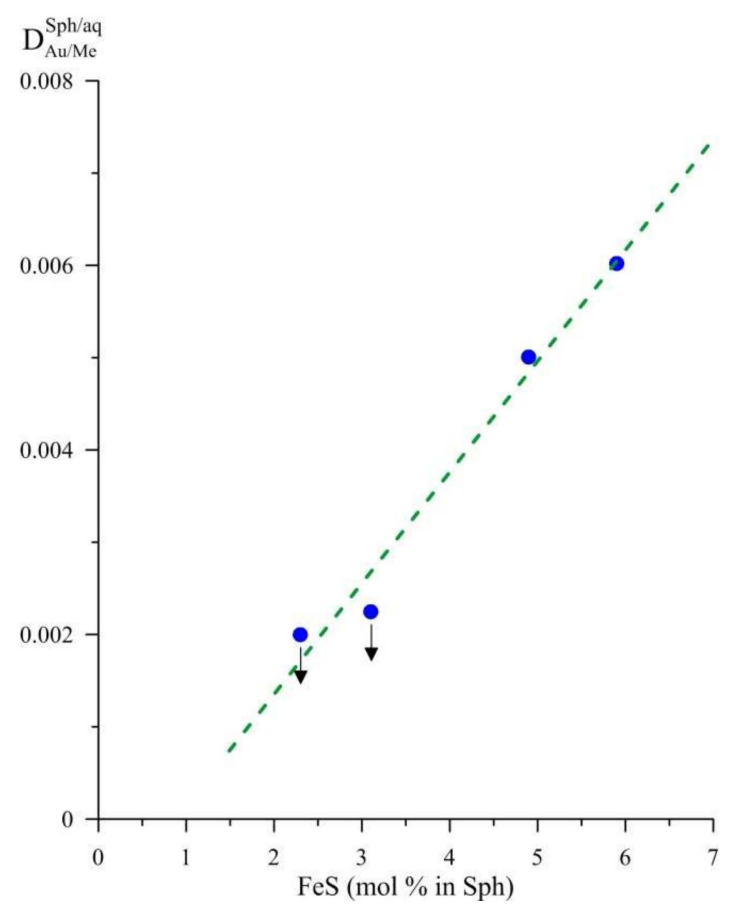

Figure 2. $\mathrm{Au} / \mathrm{Me}(\mathrm{Me}=\mathrm{Zn}+\mathrm{Fe})$ cocrystallization coefficient as a function of sphalerite composition.

Table 5 presents the Au concentrations and distribution coefficients $\left(D_{\mathrm{Au}}=C_{\mathrm{Au}}^{\mathrm{min}} / C_{\mathrm{Au}}^{\mathrm{aq}}\right)$ compared to the crystal volume (structural mode, $C_{\mathrm{Au}}^{\text {str }}$ and $D_{\mathrm{Au}}^{\text {str }}$ ) and the crystal surface (surficial mode, $C_{\mathrm{Au}}^{\text {sur }}$ and $D_{\mathrm{Au}}^{\text {sur }}$ ). The surficial mode Au contents were measured as minimums because under LA-ICP-MS analysis the sampled substance comes from 0 to $20 \mu \mathrm{m}$ depth below the surface, whereas the modified NAP surface layers enriched in impurities are usually no thicker than $1 \mu \mathrm{m}$ [7]. However, we observed that surficial Au content drastically increased in bornite, galena and sphalerite and, to a small extent, in pyrite, compared to Au contents in the bulk of the mineral crystals. Although the complexity of the system promotes development of NAP, the exception for pyrite may be due to sulfur fugacity sufficiently high to reduce the probability of pyrrhotite-like NAP formation on the pyrite crystal surface [17]. Nevertheless, this experiment supports dual partitioning of Au between surface and structure modes under mineral-fluid interactions in hydrothermal systems [7].

Table 5. Surficial and structural gold content $\left(C_{\mathrm{Au}}\right.$ in $\left.\mu \mathrm{g} / \mathrm{g}\right)$ in coexisting sulfides and corresponding mineral-fluid partition coefficients (Experiment 5).

\begin{tabular}{ccccc}
\hline Mineral & $\boldsymbol{C}_{\mathrm{Au}}^{\text {sur }}$ & $\boldsymbol{C}_{\mathrm{Au}}^{\text {str }}$ & $\boldsymbol{D}_{\mathrm{Au}}^{\text {sur }}$ & $\boldsymbol{D}_{\mathrm{Au}}^{\text {str }}$ \\
\hline Sphalerite & $2.5 \pm 1.1$ & $\leq 0.1$ & $1.0 \pm 0.4$ & $\leq 0.04$ \\
Pyrite & $11.6 \pm 7.3$ & $9.7 \pm 0.2$ & $4.5 \pm 2.8$ & $3.8 \pm 0.4$ \\
Galena & $470 \pm 30$ & $9.9 \pm 0.3$ & $184 \pm 12$ & $3.9 \pm 0.5$ \\
Bornite & $2450 \pm 320$ & $10.2 \pm 0.2$ & $957 \pm 42$ & $4.0 \pm 0.5$ \\
\hline
\end{tabular}

Note: $C_{\mathrm{Au}}^{\mathrm{str}}$ and $D_{\mathrm{Au}}^{\mathrm{str}}$ are the Au concentrations and distribution coefficients $\left(D_{\mathrm{Au}}=C_{\mathrm{Au}}^{\mathrm{min}} / C_{\mathrm{Au}}^{\mathrm{aq}}\right)$ for structural mode and $C_{\mathrm{Au}}^{\mathrm{suu}} \mathrm{and} D_{\mathrm{Au}}^{\mathrm{sur}}$ are the Au concentrations and distribution coefficients for surficial mode.

\subsection{Computational Results}

The metal species prevailing in solution are shown in Table 6. The main features of the calculated equilibrium conditions were the acidic character of high-temperature fluids $(\mathrm{pH}=3.4-3.9$, quite lower than that measured at room temperature, Table 1) and a slight reduction in the redox potential (Eh, from -0.0005 to $-0.06 \mathrm{~V}$ ). Only one case exposed a minor oxidizing value of $+0.01 \mathrm{~V}$. Nevertheless, Eh-pH variations calculated in different experiments were insignificant and likely due to variations in 
sulfur to metal ratios in batches from different experiments. On the other hand, sulfur and hydrogen sulfide activities varied distinctly (see Section 4.2).

Table 6. Results of physicochemical modelling of the isobar-isothermal equilibrium in the $\mathrm{S}-\mathrm{Zn}-\mathrm{Pb}-\mathrm{Cu}-\mathrm{Fe}-\mathrm{Cl}-\mathrm{N}-\mathrm{Au}-\mathrm{H}-\mathrm{O}$ system under the conditions of the hydrothermal experiments.

\begin{tabular}{|c|c|c|c|c|c|c|c|c|c|c|c|c|c|}
\hline \multirow{2}{*}{$\begin{array}{l}\text { Experiment } \\
\text { No. }\end{array}$} & \multirow{2}{*}{$\mathrm{pH}$} & \multirow{2}{*}{ Eh (V) } & \multicolumn{3}{|c|}{$\begin{array}{c}\text {-Log Gas } \\
\text { Fugacity (Bar) }\end{array}$} & \multicolumn{8}{|c|}{ Main Species of Metals in Fluid (Molality) } \\
\hline & & & $\mathbf{S}_{2}$ & $\mathrm{O}_{2}$ & $\mathrm{H}_{2} \mathrm{~S}$ & $\begin{array}{l}\mathrm{AuCl}_{2}^{-} \\
\times 10^{-6}\end{array}$ & $\begin{array}{l}\mathrm{AuHS}^{0} \\
\times 10^{-6}\end{array}$ & $\begin{array}{l}\mathrm{FeCl}_{2}^{0} \\
\times 10^{-2}\end{array}$ & $\begin{array}{l}\mathrm{CuCl}_{2}^{-} \\
\times 10^{-2}\end{array}$ & $\begin{array}{l}\mathrm{ZnCl}^{+} \\
\times 10^{-1}\end{array}$ & $\begin{array}{l}\mathrm{ZnCl}_{2}^{0} \\
\times 10^{-1}\end{array}$ & $\begin{array}{l}\mathrm{PbCl}_{2}^{0} \\
\times 10^{-2}\end{array}$ & $\begin{array}{l}\mathrm{PbCl}_{3}^{-} \\
\times 10^{-2}\end{array}$ \\
\hline 1 & 3.87 & -0.05 & 3.59 & 20.0 & 0.40 & 1.58 & 1.39 & 4.66 & 1.47 & 3.54 & 1.42 & 3.07 & 1.88 \\
\hline 2 & 3.90 & -0.06 & 3.75 & 20.19 & 0.39 & 2.57 & 1.23 & 8.26 & 2.60 & 3.78 & 2.02 & 4.95 & 4.28 \\
\hline 4 & 3.53 & -0.0005 & 2.42 & 20.09 & -0.23 & 3.09 & 5.36 & 2.05 & 1.50 & 4.01 & 1.44 & 3.10 & 1.90 \\
\hline 5 & 3.40 & 0.01 & 1.92 & 20.26 & -0.56 & 5.91 & 10.2 & 1.54 & 2.27 & 4.06 & 1.81 & 4.12 & 3.17 \\
\hline
\end{tabular}

\section{Discussion}

\subsection{Au Interphase Distribution and Evaluation of Gold Solubility in Minerals}

Compared to other minerals studied, galena and bornite were the best matrixes for Au under its partitioning in a multiphase hydrothermal mineral system (Table 2). Magnetite and sphalerite appeared to be poor gold scavengers, and the distribution coefficients were at a level of 300 in favor of bornite and galena $\left(D_{\mathrm{Au}}^{\mathrm{Bn} / \mathrm{Mt}} \approx 280, D_{\mathrm{Au}}^{\mathrm{Gn} / \mathrm{Sph}} \approx 350\right)$. Chalcopyrite and pyrite occupied an intermediate position $\left(D_{\mathrm{Au}}^{\mathrm{Gn} / \mathrm{Cpy}} \approx 2, D_{\mathrm{Au}}^{\mathrm{Cpy} / \mathrm{Py}} \approx 7\right.$ ). The status of Cu-pyrite in Experiment 5 (Table 2) was not seen clearly and should be specified in future work.

Taking galena as a reference mineral with Au solubility $S_{\mathrm{Au}}^{\mathrm{Gn}}=240 \mu \mathrm{g} / \mathrm{g}$ [13], the solubility of $\mathrm{Au}$ in coexisting minerals $\left(S_{\mathrm{Au}}^{\mathrm{min}}\right)$ was estimated using an expression reflecting the phase composition correlation principle [18]: $S_{\mathrm{Au}}^{\min }=C_{\mathrm{Au}}^{\min } \times S_{\mathrm{Au}}^{\mathrm{Gn}} / C_{\mathrm{Au}}^{\mathrm{Gn}}$, where $C_{\mathrm{Au}}^{\mathrm{Gn}}$ and $C_{\mathrm{Au}}^{\min }$ are the concentrations in coexisting galena and the mineral under consideration.

The data obtained (Figure 2, Table 7) show that sphalerite with elevated Fe content may be more favorable for $\mathrm{Au}$ uptake when compared to low-Fe varieties due to the higher value of the $\mathrm{Au} /(\mathrm{Zn}+\mathrm{Fe})$ cocrystallization coefficient.

Table 7. Solubility of $\mathrm{Au}$ in minerals under the parameters of hydrothermal ore formation $\left(\mathrm{T}=450-500{ }^{\circ} \mathrm{C}, \mathrm{P}=1 \mathrm{kbar}\right)$.

\begin{tabular}{cccc}
\hline Mineral & Formula & $\mathbf{S}_{\mathrm{Au}}(\boldsymbol{\mu g} / \mathbf{g})$ & Ref. \\
\hline Low-Fe Sphalerite & $(\mathrm{Zn}, \mathrm{Fe}) \mathrm{S}$ & 0.7 & This work \\
High-Fe Sphalerite & $(\mathrm{Zn}, \mathrm{Fe}) \mathrm{S}$ & 5 & This work and [4] \\
Magnetite & $\mathrm{Fe}_{3} \mathrm{O}_{4}$ & 1 & This work \\
Pyrite & $\mathrm{FeS}_{2}$ & 3 & {$[18]$} \\
Pyrite-Mn & $(\mathrm{Fe}, \mathrm{Mn}) \mathrm{S}_{2}$ & 7 & {$[19]$} \\
Pyrite-Cu & $(\mathrm{Fe}, \mathrm{Cu})_{2}$ & 10 & This work \\
Pyrrhotite & $\mathrm{Fe}_{1-x} \mathrm{~S}$ & 21 & [20] \\
Chalcopyrite & $\mathrm{CuFeS}_{2}$ & 110 & This work \\
Bornite & $\mathrm{Cu}_{5} \mathrm{FeS}_{4}$ & 140 & This work \\
Galena & $\mathrm{PbS}$ & 240 & [13] \\
\hline
\end{tabular}

One possible reason is the presence of small amounts of $\mathrm{Fe}^{3+}$ [21] that compensate for $\mathrm{Au}^{+}$ incorporation according to the scheme $\mathrm{Au}^{+}+\mathrm{Fe}^{3+} \leftrightarrow 2 \mathrm{Zn}^{2+}\left(\right.$ or $\left.\mathrm{Zn}^{2+}+\mathrm{Fe}^{2+}\right)[4,22]$. Correlation of invisible Au with Fe content in sphalerite was observed in natural samples as well [23,24]. The higher solubility of $\mathrm{Au}$ in galena and $\mathrm{Cu}$ and Fe-containing sulfides, as compared to other minerals, may be explained by the high degree of metallicity of chemical bonds in their structures [4]. Early studies of $\mathrm{Au}$ distribution between sulfides under hydrothermal conditions at $500{ }^{\circ} \mathrm{C}$ and $98 \mathrm{MPa}$ [25] are 
consistent qualitatively with the results of our experiments. Galena and bornite were determined as the most effective concentrators of gold, compared to pyrite and sphalerite, having no appreciable gold admixture in their structures. It was also shown $[25,26]$ that during the cocrystallization of pyrite and $\mathrm{Au}$ under the conditions of hydrothermal crystal growth, evenly distributed Au was not present in the crystal body in any significant amount, but was located in a thin outermost layer of several hundred nanometers thick. This result was subsequently confirmed by our growth experiments, which showed the presence on the surface of growing pyrite crystals of surficial NAP of such thickness ( $500 \mathrm{~nm})$ capable of absorbing Au (as well as other trace elements) in concentrations by three orders of magnitude higher than in the volume of the crystal $[7,17]$. The superficial gold accumulation was correlated with the metallicity of chemical bonds after the manner of structural gold content [27]. Nevertheless, often observed high contents of invisible gold in pyrite are difficult to explain from the experimental data presented here. Although this question goes beyond the scope of the present study, it is our opinion that the formation of heterogeneous crystals of pyrite with high contents of Au and As may be a consequence of a special mechanism of crystal growth specified by the agency of NAPs [7-9].

\subsection{Au/Me Cocrystallisation Coefficients and Their Variations}

According to the data (Tables 4 and 6), $D_{\mathrm{Au} / \mathrm{Zn}}$ and $D_{\mathrm{Au} / \mathrm{Fe}}$ for sphalerite decreased slightly with a reduction in $\mathrm{pH}$ and an increase in $\mathrm{Eh}, \mathrm{f}_{\mathrm{S} 2}$, and $\mathrm{f}_{\mathrm{H} 2 \mathrm{~S}}$, along with an elevation in main $\mathrm{Au}$ species $\left(\mathrm{AuCl}_{2}^{-}\right.$ and $\left.\mathrm{AuHS}^{0}\right)$ content and a decrease in main Fe species $\left(\mathrm{FeCl}_{2}^{0}\right)$ content. This effect was absent for the main species of other metals. In fact, the Fe content in the fluid trapped by the sampler in Experiment 5 was of minimal value (Table 1 ). The reduction of $D_{\mathrm{Au} / \mathrm{Me}}$ for bornite in Experiment 5 (especially in the case of $D_{\mathrm{Au} / \mathrm{Fe}}$ ) relative to Experiments 1 and 2 (Table 4) may be connected with the elevation of $\mathrm{Au}$ content in solution $\left(\mathrm{Au}^{\mathrm{aq}}\right)$, mainly as $\mathrm{AuCl}_{2}^{-}$and $\mathrm{AuHS}^{0}$ species causing a decrease in the $\mathrm{Au}^{\mathrm{Bn}} / \mathrm{Au}^{\mathrm{aq}}$ ratio. The increase in $\mathrm{Au}^{\mathrm{aq}}$ was not compensated with $\mathrm{Fe}^{\mathrm{aq}}$ elevation; instead, $\mathrm{FeCl}_{2}^{0}$ content decreased causing an increase in $\mathrm{Fe}^{\mathrm{Bn}} / \mathrm{Fe}^{\mathrm{aq}}$ and lowering of the cocrystallization coefficient $D_{\mathrm{Au} / \mathrm{Fe}}^{\mathrm{Bn}}$. Therefore, the most likely reason for the decrease in $D_{\mathrm{Au} / \mathrm{Fe}}^{\mathrm{Bn} / \mathrm{aq}}$ was the precipitation of Fe ${ }^{\text {aq }}$ under high $f_{\mathrm{S} 2}$ and $f_{\mathrm{H} 2 \mathrm{~S}}$ values, and simultaneous increase in the hydrosulfide form and, to a lesser extent, the chloride form of $\mathrm{Au}^{\mathrm{aq}}$. This effect was exhibited by $\mathrm{Cu}$ as well, but the effect was an order of magnitude weaker compared to Fe (Table 4).

\subsection{Gold/Metal Ratios in Ore-Forming Fluids}

Cocrystallization coefficients were determined experimentally to analyze the elemental composition of hydrothermal fluids from which the gold-bearing minerals precipitated. It is possible to obtain the relative (not absolute) concentration of $\mathrm{Au}$ in fluid using $D_{\mathrm{Au} / \mathrm{Me}}$, which is the ratio of $\mathrm{Au}$ to the macroelements in the mineral matrix. To extrapolate the absolute value of Au content, data on the content of cocrystallized elements of mineral matrix are required. These values can be obtained from the analysis of fluid inclusions or from data on mineral solubility under the mineral formation conditions.

Iron is known to be one of the main components of hydrothermal solutions. Its content is buffered by wall rocks, which is partly true for base metals $(\mathrm{Cu}, \mathrm{Zn}, \mathrm{Pb})$ studied in this work. The ratios $\mathrm{Au} / \mathrm{Fe}$, $\mathrm{Au} / \mathrm{Cu}$, etc. may be useful indicators for comparison of the composition of fluids of different origin, age and geodynamic background. The principal limitation of this approach is the necessity of using, solely and exclusively, the structurally-bound Au. As an example, values for cases in which Au was evenly distributed (Table 8) were far lower than incorporation limits (Table 7), and obtained using precise, sensitive and highly local (to avoid inhomogeneity) methods (SIMS, LA-ICP-MS). In our calculations, we used the most probable $D$ values (Table 8 footnotes). The low value for $D_{\mathrm{Au} / \mathrm{Fe}}^{\mathrm{Bn} / \mathrm{aq}}$ in Experiment 5 was not considered because of the reasons given in the Section 4.2. 
Table 8. Concentration of invisible gold in selected sulfide minerals $[2,28,29]$ and calculated $\mathrm{Au} / \mathrm{Me}$ ratios in mineral-forming fluids.

\begin{tabular}{|c|c|c|c|c|c|}
\hline \multirow{2}{*}{ Deposit } & \multirow{2}{*}{ Age, Setting, Type } & \multirow{2}{*}{ Mineral } & \multirow{2}{*}{$C_{\mathrm{Au}}(\mathrm{ppm})$} & \multicolumn{2}{|c|}{$\begin{array}{c}\mathrm{Au} / \mathrm{Me} \\
\text { in Ore-Forming Fluid }^{a}\end{array}$} \\
\hline & & & & $\mathrm{Au} / \mathrm{Fe}$ & $\mathrm{Au} / \mathrm{Cu}$ \\
\hline \multirow{2}{*}{ Estrades, Quebec [2] } & \multirow{2}{*}{$\begin{array}{c}\text { Archean, Superior Province, } \\
\text { volcanic-sedimentary } \\
\text { sequence }\end{array}$} & Pyrite & $0.67 \pm 0.53$ & $(9 \pm 7) \times 10^{-5}$ & - \\
\hline & & Chalcopyrite & $0.13 \pm 0.09$ & $(1 \pm 0.7) \times 10^{-6}$ & $(2.1 \pm 1.4) \times 10^{-5}$ \\
\hline \multirow{2}{*}{ Mobrun, Quebec [2] } & \multirow{2}{*}{$-“-$} & Pyrite & $1.41 \pm 0.23$ & $(1.9 \pm 0.3) \times 10^{-4}$ & - \\
\hline & & Chalcopyrite & $1.1 \pm 0.8$ & $(8 \pm 6) \times 10^{-6}$ & $(1.8 \pm 1.3) \times 10^{-4}$ \\
\hline \multirow{4}{*}{$\begin{array}{l}\text { HW, British } \\
\text { Columbia [2] }\end{array}$} & \multirow{4}{*}{$\begin{array}{c}\text { Triassic, Coastal Insular belt } \\
\text { volcanic-sedimentary hosted } \\
\text { massive sulfides }\end{array}$} & Pyrite & $0.25 \pm 0.09$ & $(3.4 \pm 1.2) \times 10^{-5}$ & \\
\hline & & $\begin{array}{l}\text { Chalcopyrite } \\
\text { (coarse) }\end{array}$ & $0.19 \pm 0.10$ & $(1.5 \pm 0.8) \times 10^{-6}$ & $(3.0 \pm 1.6) \times 10^{-5}$ \\
\hline & & $\begin{array}{l}\text { Chalcopyrite } \\
\text { (fine) }\end{array}$ & $3.0 \pm 1.3$ & $(2.3 \pm 1) \times 10^{-5}$ & $(4.8 \pm 2.1) \times 10^{-4}$ \\
\hline & & Bornite & $0.67 \pm 0.20$ & $(2.5 \pm 0.8) \times 10^{-6}$ & $(6.2 \pm 1.9) \times 10^{-5}$ \\
\hline \multirow{4}{*}{$\begin{array}{l}\text { Crown Point, British } \\
\text { Columbia [28] }\end{array}$} & \multirow{4}{*}{$\begin{array}{l}\text { Jurassic, Skarn-hosted } \\
\text { mineralization at Rossland }\end{array}$} & Chalcopyrite $^{b}$ & $\begin{array}{l}0.011 \\
0.027\end{array}$ & $\begin{array}{l}0.8 \times 10^{-7} \\
2.1 \times 10^{-7}\end{array}$ & $\begin{array}{l}1.8 \times 10^{-6} \\
4.3 \times 10^{-6}\end{array}$ \\
\hline & & Chalcopyrite $^{c}$ & 0.095 & $7.3 \times 10^{-7}$ & $1.5 \times 10^{-5}$ \\
\hline & & $\begin{array}{l}\text { Magnetite } \\
\text { (crack) }^{d}\end{array}$ & $\begin{array}{c}0.015 \\
0.17\end{array}$ & $\begin{array}{l}1.6 \times 10^{-5} \\
1.8 \times 10^{-4}\end{array}$ & - \\
\hline & & $\begin{array}{l}\text { Magnetite } \\
{\text { (matrix })^{d}}^{\text {Mat }}\end{array}$ & $\begin{array}{l}0.003 \\
0.015\end{array}$ & $\begin{array}{l}3.2 \times 10^{-6} \\
1.6 \times 10^{-5}\end{array}$ & - \\
\hline \multirow{4}{*}{$\begin{array}{l}\text { Lodestar Prospect, } \\
\text { Newfoundland [29] }\end{array}$} & \multirow{4}{*}{$\begin{array}{c}\text { Neoproterozoic, } \\
\text { magmatic-hydrothermal } \\
\text { breccia related to a porphyry } \\
\text { intrusive system }\end{array}$} & Pyrite & 0.73 & $9.8 \times 10^{-5}$ & - \\
\hline & & Chalcopyrite & 1.48 & $1.1 \times 10^{-5}$ & $2.4 \times 10^{-4}$ \\
\hline & & Pyrite & 1.33 & $1.8 \times 10^{-4}$ & - \\
\hline & & Chalcopyrite & 0.63 & $4.8 \times 10^{-6}$ & $1.0 \times 10^{-4}$ \\
\hline $\begin{array}{l}{ }^{a} D \text { values for } \\
D_{\mathrm{Au} / \mathrm{Fe}}^{\mathrm{Mt} / \mathrm{aq}}=0.0013 \\
\text { skarns. }^{c} \text { Arseni }\end{array}$ & $\begin{array}{l}\text { culations: } D_{\mathrm{Au} / \mathrm{Fe}}^{\mathrm{Py} / \mathrm{aq}}=0.016 \text {, } \\
\text { Iajor element concentration } \\
\text { karns. }{ }^{d} \text { Magnetite skarns. }\end{array}$ & $\begin{array}{l}\text { Cpy/aq }=0.43 \\
\mathrm{Au} / \mathrm{Fe} \\
\text { are from stoich }\end{array}$ & $\begin{array}{l}\mathrm{l} / \mathrm{aq} \\
\mathrm{u} / \mathrm{Fe} \\
\text { etric miner }\end{array}$ & $\begin{array}{l}\text { py/aq }=0.018, D \\
\text { u/Cu } \\
\text { rmulas. }{ }^{b} \text { Low- }\end{array}$ & $\begin{array}{l}\mathrm{aq}=0.017 \\
\mathrm{Cu} \\
\text { enic sulfide }\end{array}$ \\
\hline
\end{tabular}

It is interesting to note that pyrite and magnetite crystallized from solutions richer in $\mathrm{Au}(\mathrm{Au} / \mathrm{Fe}=n$ $\left.\times 10^{-4}-n \times 10^{-5}\right)$ than chalcopyrite and bornite $\left(\mathrm{Au} / \mathrm{Fe}=n \times 10^{-5}-n \times 10^{-7}\right)$. The $\mathrm{Fe} / \mathrm{Cu}$ ratio in the fluids $(\mathrm{Au} / \mathrm{Cu}: \mathrm{Au} / \mathrm{Fe})$ was equal to $21 \pm 1$. A larger number of samples from deposits of different genesis, and characterized by reliable geological-structural positions and timing, is required for more representative conclusions.

\subsection{Dualism of Gold Partitioning}

Table 5 shows the elevation of the Au distribution coefficient $D^{\mathrm{cr} / \mathrm{aq}}$ for surficial layers of crystal, especially in the case of bornite and galena. Tauson et al. [7] interpreted this effect as a duality of distribution coefficient; the dualism being due to the fact that the surficial NAP had its own $D^{\text {cr/aq }}$ value which was higher than that of the crystal interior. The NAP represents the chemically modified and structurally reconstructed surface layer of a crystal. Its capability to absorb high amounts of incompatible elements is possibly due to the presence of unsaturated chemical bonds, and structural disorder, that weaken the crystal-chemical control for element incorporation. The duality of $D^{\mathrm{cr} / \mathrm{aq}}$ is related to a serious problem of Au behavior in low-temperature $\left(50-100^{\circ} \mathrm{C}\right)$ geothermal systems. In such systems (hot springs, fumaroles), gold partition into precipitates is $10^{6}$ and more the difference between solid and liquid phases [30], which is much greater than for high-temperature hydrothermal systems (see [7,31] and Table 3 in this work). A similar situation was reported for pyrite from hydrothermal clay at volcanic thermal fields in Southern Kamchatka (Russia) where the $D^{\text {cr/aq }}$ value amounted to $\sim 10^{5}$ [32]. The mechanism of such high fractionation is not fully understood. It is hardly governed by Au adsorption with sulfides [30] because the amount of sulfide minerals was too low to decrease the Au concentration in solution to such low values. The duality of $D^{\mathrm{cr} / \mathrm{aq}}$ can contribute to this high-fractionation effect to approximately two orders of magnitude, especially for small crystals. 
However, an increase of five to six orders of magnitude may be explained (assuming no error in liquid phase sampling) only by participation of Au clusters or nanoparticles, which are difficult to distinguish in fine precipitates or in real mineral crystals [32].

\section{Conclusions}

Multiphase, multicomponent hydrothermal systems can be used for experimental and physicochemical modelling of gold distribution, segregation, and cocrystallization. Gold behaves variously in ore minerals: $\mathrm{Au}$ is a compatible element in galena, bornite, and chalcopyrite; Au is less compatible with pyrite, and incompatible with sphalerite and magnetite. The distribution and cocrystallization coefficients characterize the property of a mineral as a gold concentrator because all coexisting minerals were grown together under similar conditions.

Computer modelling allowed us to identify the factors affecting gold speciation and partitioning in the studied sulfide hydrothermal system. The most important factor was the increase in $S_{2}$ and $\mathrm{H}_{2} \mathrm{~S}$ fugacity causing the main $\mathrm{Au}$ species $\left(\mathrm{AuCl}_{2}^{-}\right.$and $\left.\mathrm{AuHS}^{0}\right)$ content to increase and the main iron species $\left(\mathrm{FeCl}_{2}^{0}\right)$ to decrease.

Application of the phase composition correlation principle, using galena as a reference mineral, allowed us to estimate $\mathrm{Au}$ solubility in a number of minerals for hydrothermal parameters (i.e., 450-500 ${ }^{\circ} \mathrm{C}, 1 \mathrm{kbar}$ pressure). The solubility values were much higher (up to two orders of magnitude) for galena and mixed $\mathrm{Cu}, \mathrm{Fe}$-sulfides (bornite, chalcopyrite) compared to sphalerite, magnetite and pyrite, which may be due to the high metallicity of the chemical bonds.

The anomalous gold uptake by galena crystals in one experiment supports the idea that the mechanism of crystal growth strongly influences gold distribution due to its segregation at crystal mosaic-block boundaries enriched in Cu-containing submicron phases. The comparative LA-ICP-MS study of the bulk and surficial gold admixtures revealed elevated Au content in the surficial crystal layers of coexisting minerals that were maximal for bornite and galena and up to two orders of magnitude greater compared to the crystal volume. This reflects the presence of surficial NAP and associated dualism in the distribution coefficient of gold. However, this effect is not enough to explain the very high gold fractionation into precipitates observed in low-temperature geothermal systems.

The most reliable cocrystallization coefficients determined experimentally were used to analyze the elemental composition of hydrothermal fluids from which the minerals precipitated. Our estimates, using $\mathrm{Au}$ contents in pyrite, chalcopyrite, magnetite and bornite from volcanic-sedimentary, skarn-hosted, and magmatic-hydrothermal sulfide deposits, showed a range of Au/Fe ratios in fluids of $n \times 10^{-4}-n \times 10^{-7}$ and $\mathrm{Au} / \mathrm{Cu}$ ratio of $n \times 10^{-4}-n \times 10^{-6}$. Pyrite and magnetite possibly crystallized from solutions enriched in Au compared to solutions from which chalcopyrite and bornite precipitated. The approach based on cocrystallization coefficients is useful in the reconstruction of the composition of fluids of different geological ages and geochemical environments.

Author Contributions: S.L. coordinated experiments, LA-ICP-MS analysis, and computer modelling and contributed to the interpretation of results. V.T. formulated the problem and provided the explanation of the phenomena observed. V.B. realized physicochemical modelling with PC Selector and interpreted the results. All authors have read and agreed to the published version of the manuscript.

Funding: The research was performed within the framework of state-ordered project IX.125.3.4, No. 0350-2019-0003 which was partially funded by the Russian Foundation for Basic Research (grant No. 18-05-00077 and 20-05-00142) and integration project No. 1.2 of the Irkutsk Scientific Center SB RAS.

Acknowledgments: We want to acknowledge Dmitriy Babkin and Taisa Pastushkova for their assistance with the experimental and analytical work. Cooperation with the scientists at the Common Use Center's 'Isotope and Geochemical Studies' of the Vinogradov Institute of Geochemistry SB RAS and 'Ultra-microanalysis' of the Limnological Institute of SB RAS are greatly appreciated.

Conflicts of Interest: The authors declare no conflict of interest. 


\section{References}

1. Yang, X.-M.; Lentz, D.R.; Sylvester, P.J. Gold contents of sulfide minerals in granitoids from southwestern New Brunswick, Canada. Miner. Depos. 2006, 41, 369-386. [CrossRef]

2. Cook, N.J.; Chryssoulis, S.L. Concentrations of "invisible gold" in the common sulfides. Can. Mineral. 1990, 28, 1-16.

3. Cabri, L.J. The distribution of trace precious metals in minerals and mineral products. Mineral. Mag. 1992, 56, 289-308. [CrossRef]

4. Tauson, V.L.; Mironov, A.G.; Smagunov, N.V.; Bugaeva, N.G.; Akimov, V.V. Gold in sulfides: State of the art occurrence and horizons of experimental studies. Russ. Geol. Geophys. 1996, 37, 1-11.

5. El-Bouseily, A.M.; El-Dahhar, M.A.; Arslan, A.I. Ore-microscopic and geochemical characteristics of gold-bearing sulfide minerals, El Sid Gold Mine, Easern Desert, Egypt. Miner. Depos. 1985, 20, 194-200. [CrossRef]

6. Wohlgemuth-Ueberwasser, C.C.; Viljoen, F.; Petersen, S.; Vorster, C. Distribution and solubility limits of trace elements in hydrothermal black smoker sulfides: An in-situ LA-ICP-MS study. Geochim. Cosmochim. Acta 2015, 159, 16-41. [CrossRef]

7. Tauson, V.L.; Lipko, S.V.; Smagunov, N.V.; Kravtsova, R.G. Trace element partitioning dualism under mineral-fluid interaction: Origin and geochemical significance. Minerals 2018, 8, 282. [CrossRef]

8. Tauson, V.L.; Lipko, S.V.; Smagunov, N.V.; Kravtsova, R.G.; Arsent'ev, K.Y. Distribution and segregation of trace elements during the growth of ore mineral crystals in hydrothermal systems: Geochemical and mineralogical implications. Russ. Geol. Geophys. 2018, 59, 1718-1732. [CrossRef]

9. Tauson, V.L.; Lipko, S.V.; Arsent'ev, K.Y.; Smagunov, N.V. Crystal growth through the medium of nonautonomous phase: Implications for element partitioning in ore systems. Crystallogr. Rep. 2019, 64, 496-507. [CrossRef]

10. Zajacz, Z.; Hanley, J.J.; Heinrich, C.A.; Halter, W.E.; Guillong, M. Diffusive reequilibration of quartz-hosted silicate melt and fluid inclusions: Are all metal concentrations unmodified? Geochim. Cosmochim. Acta 2009, 73, 3013-3027. [CrossRef]

11. Karpov, I.K.; Chudnenko, K.V.; Bychinskii, V.A.; Kulik, D.A.; Avchenko, O.V. Minimization of Gibbs free energy in geochemical systems by convex programming. Geochem. Int. 2001, 39, 1108-1119.

12. Chudnenko, K.V. Thermodynamic Modeling in Geochemistry: Theory, Algorithms, Software, Applications; Geo Publications: Novosibirsk, Russia, 2010.

13. Tauson, V.L.; Smagunov, N.V.; Akimov, V.V.; Datkov, V.A. Mechanisms and species of gold incorporation into crystals of cadmium, lead, and iron sulfides. Russ. Geol. Geophys. 2008, 49, 594-601. [CrossRef]

14. Tauson, V.L.; Smagunov, N.V.; Lipko, S.V. Cocrystallization coefficients of Cr, V, and Fe in hydrothermal ore systems (from experimental data). Russ. Geol. Geophys. 2017, 58, 949-955. [CrossRef]

15. Abramovich, M.G.; Shmakin, B.M.; Tauson, V.L.; Akimov, V.V. Mineral topochemistry: Anomalous trace-element concentrations in solid solutions with defect structures. Int. Geol. Rev. 1990, 32, 608-615. [CrossRef]

16. Chouinard, A.; Paquette, J.; Williams-Jones, A.E. Crystallographic controls on trace-element incorporation in auriferous pyrite from the Pascua epithermal high-sulfidation deposit, Chile-Argentina. Can. Mineral. 2005, 43, 951-963. [CrossRef]

17. Tauson, V.L.; Babkin, D.N.; Lustenberg, E.E.; Lipko, S.V.; Parkhomenko, I.Y. Surface typochemistry of hydrothermal pyrite: Electron spectroscopic and scanning probe microscopic data. I. Synthetic pyrite. Geochem. Int. 2008, 46, 565-577. [CrossRef]

18. Tauson, V.L. Gold solubility in the common gold-bearing minerals: Experimental evaluation and application to pyrite. Eur. J. Mineral. 1999, 11, 937-947. [CrossRef]

19. Tauson, V.L.; Babkin, D.N.; Akimov, V.V.; Lipko, S.V.; Smagunov, N.V.; Parkhomenko, I.Y. Trace elements as indicators of the physicochemical conditions of mineral formation in hydrothermal sulfide systems. Russ. Geol. Geophys. 2013, 54, 526-543. [CrossRef]

20. Tauson, V.L.; Smagunov, N.V.; Pastushkova, T.M. Gold incorporation into pyrrhotite and the influence of nonautonomous phases on its distribution. Geochem. Int. 2005, 43, 86-89.

21. Lepetit, P.; Bente, K.; Doering, T.; Luckhaus, S. Crystal chemistry of Fe-containing sphalerites. Phys. Chem. Miner. 2003, 30, 185-191. [CrossRef] 
22. Tonkacheev, D.E.; Chareev, D.A.; Abramova, V.D.; Kovalchuk, E.V.; Vikentyev, I.V.; Tagirov, B.R. The substitution mechanism of $\mathrm{Au}$ in In-, Fe- and In-Fe-bearing synthetic crystals of sphalerite, based on the data from EPMA and LA-ICP-MS study. Litosfera 2019, 19, 148-161. [CrossRef]

23. Asadi, H.H.; Voncken, J.H.L.; Hale, M. Invisible gold at Zarshuran. Iran. Econ. Geol. 1999, 94, 1367-1374. [CrossRef]

24. Vikentyev, I.V. Invisible and microscopic gold in pyrite: Methods and new data for massive sulfide ores of the Urals. Geol. Ore Depos. 2015, 57, 237-265. [CrossRef]

25. Mironov, A.G.; Al'mukhamedov, A.I.; Geletii, V.F.; Glyuk, D.S.; Zhatnuev, N.S.; Zhmodik, S.M.; Konnikov, E.G.; Medvedev, A.Y.; Plyusnin, A.M. Experimental Studies of Gold Geochemistry Using the Method of Radioisotope Indicators; Nauka: Novosibirsk, Russia, 1989. (In Russian)

26. Mironov, A.G.; Geletii, V.F. Study of gold distribution in synthetic pyrites using Au-195 radioisotope. Dokl. Akad. Nauk. SSSR 1978, 241, 1428-1431.

27. Bugaeva, N.G. Finely Dispersed ("Invisible") Gold in Sulfides: An Experimental Study of the Formation Mechanism; LAP Lambert Academic Pub.: Saarbrucken, Germany, 2011.

28. Wilson, G.C.; Rucklidge, J.C.; Kilius, L.R. Sulfide gold content of skarn mineralization at Rossland, British Columbia. Econ. Geol. 1990, 85, 1252-1259. [CrossRef]

29. Hinchey, J.G.; Wilton, D.H.C.; Tubrett, M.N. A LAM-ICP-MS study of the distribution of gold in arsenopyrite from the Lodestar prospect, Newfoundland, Canada. Can. Mineral. 2003, 41, 353-364. [CrossRef]

30. Pope, J.G.; Brown, K.L.; McConchie, D.M. Gold concentrations in springs at Waiotapu, New Zealand: Implications for precious metal deposition in geothermal systems. Econ. Geol. 2005, 100, 677-687. [CrossRef]

31. Pokrovski, G.S.; Kokh, M.A.; Proux, O.; Hazemann, J.-L.; Bazarkina, E.F.; Testemale, D.; Escoda, C.; Boiron, M.-C.; Blanchard, M.; Aigouy, T.; et al. The nature and partitioning of invisible gold in the pyrite-fluid system. Ore Geol. Rev. 2019, 109, 545-563. [CrossRef]

32. Tauson, V.L.; Rychagov, S.N.; Akimov, V.V.; Lipko, S.V.; Smagunov, N.V.; Gerasimov, I.N.; Davletbaev, R.G.; Loginov, B.A. Role of surface phenomena in concentrating incompatible elements: Au in pyrite from hydrothermal clays at thermal fields in Southern Kamchatka. Geochem. Int. 2016, 53, 973-986. [CrossRef]

(C) 2020 by the authors. Licensee MDPI, Basel, Switzerland. This article is an open access article distributed under the terms and conditions of the Creative Commons Attribution (CC BY) license (http://creativecommons.org/licenses/by/4.0/). 